\title{
Multiple Discourses On Sexuality Implications For Translating Sexual Wellness Concept Into Action Strategies In A Kenyan Context
}

\author{
Beth Maina Ahlberg \\ Skaraborg Institute for Research and Development, Skövde and \\ Department of Women and Children's Health, Uppsala University, Sweden \\ E-mail: beth@skaraborg-institute.se \\ Anne Kamau \\ Institute for Development Studies (IDS), University of Nairobi, Kenya \\ E-mail:avwairimu@yahoo.com \\ Faith Maina \\ State University of New York, Oswego, USA \\ E-mail:maina@oswego.edu
}

Asli Kulane

Division of International Health, Karolinska Institutet, Sweden

E-mail:asli.kulane@ki.se

\section{Abstract}

This Paper attemps to map, drawing mainly from HIV and AIDS prevention interventions, the multiple discourses on sexuality. The aim is to provide a picture of the challenges and opportunities in transforming the concept of sexual wellness currently being articulated. This is a move from the commonly held view of sexuality as a threat to health, to one promoting sexual wellness or positive view of sexuality. A postcolonial conceptual perspective is used to help grasp the multiple-realities emerging from the historical influences on Africa and for reflexivity on the ambivalences and representations of Africa and African culture including sexuality.

Key words: sexuality, complexity, moral sensitivity, postcolonial, HIV and AID

\section{Introduction}

This paper is principally concerned with sexuall wellness. It asks: how can sexuall wellness be made a policy? What would be required to make positive the negative 
view of sexuality in an African context? How will actors in multiple positions and which intersect in diverse and complex ways be mobilised in this direction? These questions derive frm two case studies recent case studies: a 2004 study in central Kenya on HIV prevention and earlier studies on male circumstision by Ahlberg et al. (1997). In the 2004 study, parents expressed concern that the young people had turned Kesha, an evening Christian fellowship into a space for sexual orgy.

The evidence was used condoms, littered all over after worship. As a space for Christian worship, most parents, including non-faithfuls, allowed their children with ease, to participate until evidence revealed the fellowship could be fulfilling both spiritual and sexual needs.

The parents thus urged the local chief to ban Kesha. In the 1997 studies,teachers as well as pupils were surprised to learn that there had been a practice in their community, known as Ngwiko in which young men and women were, after initiation allowed to sleep together, to explore and enjoy each other without penetrative sex. Younger parents too were surprised that the community had such elaborate sexual education and sexual discipline, a kind of reflective moment on the dilemmas they faced today.

The paper addresses the complex questions raised above with the aid of a post-colonial conceptual framework that allows for us to underscore the historical processes of change, but more significantly to highlight the emerging conditions of double-reality, multiple power players and ambivalences in all complex realities when thinking of changing the mind-set on sexuality.

We proceed first, briefly, with HIV/AIDS interventions followed by a discussion of the post-colonial perspective which we then apply to the subject of our concern.

\section{AIDS and Quest for Change in Sexual Behaviour}

The discovery of the causal link between the AIDS-virus and sexual behaviour in the early 1980s, coupled with lack of effective biomedical or technological fixes, led to a surge of interest and concern on sexual behaviour change as the main option to prevent the spread of the AIDS-virus.

The assumption was that individuals could, with information, or as moral agents be persuaded to change sexual behaviours exposing them and their sexual partners to the risk of infection (Leichter 1991, Sears 1991).

Two lines of preventive action were advocated: premarital sexual abstinence and fidelity within marriage; both are foundational principles and expectations from a Christian moral discourse (Messer 2004). Marriage is, in this context, 
the only legitimate arena for sexual expression.

Any sexual expression outside of this boundary is condemned as sin. Condom use is the second option mostly advocated in public health discourse seemingly implying that sexual intercourse with more than one partner is legitimate as long as protection is used during coitus or that people can have sexual pleasure in the ways they choose. In reality however, there is little reference to sexual pleasure and sexuality as a health risk is what has been drummed.

These two preventive strategies, informed by Christian morality and biomedical/public health concerns, pose dilemmas: How do individuals and groups interpret and act on the technical and Christian moral scripts on sexuality in diverse contexts? And do their actions in turn influence the discourses or scripts and in what ways? We use discourse from a Focaultdian perspective to refer to the script or speech and more significantly to the situated social practice in its relationship to agent power and authority (Rabinow 1994, Lutz and Abu-Lughod 1990).

The two discourses and more so their influence on sexuality cannot be meaningfully discussed without focusing on western societal influences on Africa (Feffer 2007, Klein 2007). More significantly, it is necessary to understand some of the paradoxes emerging as a result of the historical influences especially in relation to the representations of Africa. A major impact of the European colonial expansion and ensuing development discourse and practice is the near suffocation of the African cultural and moral systems in spite of which, the same African systems are represented as though they still are in their original form. It is a writing of Africa as "epitomising the intractable, the mute, the abject or the other worldly" (Mbebe and Nutall, 2004:348). This picture of Africa "as an object apart from the world, or as an example of something else" underplays the "embeddedness in multiple elsewheres of which the continent actually speaks" (Ibid:348). Such interrogation makes postcolonial lenses plausible for grasping the emerging patterns as well as identifying avenues for change.

\section{A Postcolonial Perspective}

The meaning of the term postcolonial is hotly contested. The issue of contestation centres on whether the word "post" means after colonisation. Anne McClintock (1992) strongly cautions against an enthusiastic embrace of the term postcolonial for the reason that it gives the impression of decolonisation based on a historical linear progress, or conceptualised along time rather than power, thus avoiding the global situation as a multiplicity of powers and histories. She notes that the 
current use of "post this" or "post that" marks a global crisis in the ideology of the future especially the ideology of progress. Postcoloniality is therefore a condition or process that has generated a kind of double-reality and double consciousness of power with new and old formations at work all at once. For Mbembe (1992), postcoloniality is a state of multiple temporarities where Africa is evolving in multiple and overlapping directions simultaneously. Thus, the postcolonial should interrogate the present by questioning the fixed sense of the self and historical certainties to allow for exploring avenues through which subjectivities are constructed, maintained and contested (Chambers, 1999).

This is the line we adopt as it would help to reposition the dominant and the marginalised on the stage of a cultural discourse, challenging the representations of the colonised and colonising cultures in binary forms with essential, unchanging features (Narayan, 2000). More significantly, it allows reflection on the specific ways the African systems including those regulating sexuality were and continue to be nearly suffocated, silenced, stereotyped and stigmatised (Ahlberg 1994, 2008, Ani 1994).

$\mathrm{HIV}$ and AIDS has generated such conflicting voices regarding cultures and sexualities in the African contexts. In a historical analysis of the response to AIDS in western countries, Baldwin (2005:10) notes how the view of Africans sodomising or alternatively eating apes became an image in Western thinking. Many Africans and African governments responded initially to AIDS by defending themselves against Western images therby losing time in responding to the virus. The stress on marriage boundary is advocated in Christian as well as in many indigenous African moral regimes as is clear from the second case Ngwiko above. However, the different regimes have unique rules, norms and logic which may appear immoral viewed from the perspectives of the other. The seemingly open sexualities in some societies in Africa were for example, condemned as promiscous by the early Christian missionaries (Ahlberg 1994, Ani 1994) as was the case with the Ngriko practice.

It can be argued that the missionary condemnation at the time reflected their active role in the colonisation process where they were part of the colonial dominating powers, used as the software to win through converting the African souls or as the handmaidens of information gatherers and adjuncts of corporate penetration described by Feffer (2007) in the case of Latin America or to divide the local people along religious lines as was the case in India under the British colonial rule (Hallinan 2007). The missionaries wore an extra coat, providing education to produce a local elite (Shivji 2007), using a language of bringing good news and civilising the savages. The education was, as Mitchell and Salsbury (1996) argue in the case of Tanzania, however designed to prepare young people for the service of the colonial state by only teaching the values of the colonial 
society. It was therefore intended to produce half-baked individuals, but it is here that the near sufforcation of local values was entrenched. It is hardly surprising that the missionaries failed to see that sexual transgression outside marriage was similarly condemned in some societies in Africa (Ahlberg 1994, Mugambi 1989). The bone of contention however seemed to be how sexual pleasure ${ }^{1}$ was expressed.

The civilising mission did not end at independence. There is, according to Feffer (2007), a resurgence of religious fervor after the end of the cold war with an unprecedented number of Western humanitarian organisations including evangelicals (Hearn 2004). Chamberlain (2006) shows that evangelising is not limited to some remote village in Africa, although most international funding through faith based organazations (FBOs) may still go to rural areas (Birdsall 2005). Many humanitarian organisations including evangelical missionaries justify their continued presence in African countries as a mission to help in what is now popularly known as poverty reduction (Shivji 2007, Marshall and Taylor 2007, Hearn 2002) and more lately for promoting peace and governance. However, besides the hidden agendas, some of which bring about (Harmon-Snow,2007, Klein 2007), the explanations for the continuesd presence are framed in ways that reveal ambivalences when dealing with Africa. We discuss this in the section that follows.

\section{Ambivalences in Responding to African Conditions}

Three texts are presented as examples to illuminate the different ways ambivalence is commonly expressed by Western scholars and development agencies when responding to culture and sexuality in African contexts. The three texts present an Africa which is still virgin, never been tampered with or one that is obstinate and oblivious to the rythms of change forced on to Africa. Two areas of cultural practice in Kenya illuminate similar ambivalences about change among the Africans themselves.

The first text is by Marshall and Taylor (2006) on African church leaders and their selective reading of the bible. Marshall and Taylor observed that many African church leaders accept prevailing values from their societies, rather than examining the compatibility of those values with biblical teaching (2006:368). According to them, the African church leaders read only those parts similar to their local values, which mostly discriminate women, causing a great deal of suffering to women. Their idea of mission is therefore to rescue African women from the fangs of patriarchal control. ${ }^{2}$

The second text by Green (2003) advances a theory of chastity which he 
argues is part of the African cultural heritage. He criticizes, using Uganda as an example, the strategy of risk reduction and condom promotion in HIV and AIDS. He, however, fails to mention the shifts taking place in what he calls the African cultural heritage; the current tensions facing parents and their children arising from these shifts or the role of western Christian missionaries His attacks and arrogance when dismissing other American anthropologists who oppose his position on condom promotion (Kroeger 2003, Feldman 2003), and his argument that they do so for fear of loosing the financial support they previously enjoyed, suggest that he is less concerned about AIDS in Africa but with advocating a religious ideological stand. ${ }^{3}$ The suffering from AIDS merely offers a type of natural context for evangelising and re-missionising of Africa.

The third text, edited by Signe Arnfred (2006 focuses on how Africa's insider perspectives on sexuality have been ignored, silenced, stereotyped or erased in mainstream thinking since the colonial era. Women were represented as passive victims of patriarchal control needing rescue. According to the text, emphasis on procreative aspects of sexuality made invisible the expressions of sexual pleasure and desires. Colonial and ensuing devolopment discourses and practice thus produced and reproduce the view of an African sexuality - savage, uncontrollable, exotic, irrational and primitive.

Despite this powerful mapping, Arnfred still blames Mbeki and the African Renaissance Movement for the revival of virginity testing that has shown its face in the context of AIDS. In her critic of Mbeki and the African Renaissance, she fails to see the new religious landscape emerging worldwide, especially the expansion of the more fundamentalist Western Evangelical and Pentecostal Christian Missions. Moreover, she ignores a number of related practices including the selective funding systems which use a carrot and stick approaches to force receivers of aid to bow to donor conditionalities (Hoodbhoy et al 2005), the violence entailed in crisis or disaster capitalism and related economic shock therepy policies forced on to poor countries by the international financial institutions in the name of economic recovery (Klein 2007).

While the three texts above and more so the ambivalence of the authors can be understood as part of the "othering" process rooted in the history of European colonisation of Africa and in their postcolonial relations, interpretations of culture and sexuality by the Africans themselves are similarly of concern. In their defence against outside attacks, a common response among Africans is: "this is or is not African culture." For instance, gender violence, genital cutting, multiple sexual partners, polygamy etc may thus be explained in response to the outsider inquirer. There are issues strongly categorised as "un-African" as is clearly evident from debates currently ranging against homosexuality in many African countries especially after South Africa approved a bill recognising same 
sex marriage (Kuppan and Quintal 2006). Here too, the defence of African culture, depends less on reflexivity, critical analysis or self questioning of the cultural heritage being defended. What is portrayed is an Africa that has not been touched by the rest of the world or alternatively as obstinately holding on to its heritage. Two examples from a Kenuyan context may illustrate the defence of African culture by Africans.

The first is what came to be known as the "Kenyan theory of love." The theory evolved when in 1978, the Kenyan parliament introduced the marriage bill which among other things had a clause against wife-beating. The bill would have gone a long way to promote gender equality and improve the welfare of women and children in the case of death of a husband or after divorce. Nevertheless, the bill was shelved largely because of the wife-beating clause. The men, in the male dominated parliarment, argued that they would have no means of demonstrating their love to their wives. According to one member of parliament, the bill would make it impossible for men to teach their wives "manners", while another added that African women loved their men when they are slapped, but also argued with consensus from most men, that the proposed legislation was "very un-African" (Time Magazine 1979, JAL 1979). There was little reflection by the Kenyan male parliamentarians on the socially instituted checks previously protecting women and children against abuse.

The second example is the practice of male circumcision. Our intention is not to focus on male circumcision just because it is now increasingly promoted in the public health discourse as a cultural practice, appropriate in the prevention of HIV and AIDS (Green 2003). Neither could we agree more with the health benefit reasoning advanced particularly given the presence of confounding factors such as poor sanitation and lack of adequate water to maintain cleanliness in areas where it is promoted.

Nonetheless, in those areas where it is a tradition, it could be undergoing change which counter the preventive status, for which it is being promoted. The policy silence on this is deafening. Studies in central Kenya (Ahlberg 1997, Kamau et al 2006, Kamau 2007) show how male circumcision has changed from an institution, used to impart cultural values, knowledge and the moral standing or Ubuntu to the young men, to one where genital cutting is devoid of the educative functions. This emptiness has not reduced the importance of the cutting, although a major question asked by school boys concerns the social meaning of circumcision (Ahlberg 1997).

Yet, from another perspective it is not as devoid of cultural meanings as we claim and this is where the challenge seems to be. A good deal of its traditional form and meanings, for example, transforming boys into adult men is still embraced. The term Kugimara or making adult is used even for boys under 
fifteen years. The parents still provide a separate room or house- Thingira or Kiumbu- where female relatives are not allowed in. The counselor-Mutiiri- who used to be a man of immense knowledge on cultural values and was known and chosen by the parents, is today mainly left to the boys to chose. The boys mostly chose equally young men recently circumcised. The fact that circumcision is still universal has left a heavy institutional burden on the young men who in turn have interpreted it to fit their current contexts and realities. Two rituals practiced or adopted by the boys to suit their realities are particularly important from a masculinity formation and prevention of HIV.

The first is what the boys call "buying the road licence" where the newly circumcised is expected to offer money or buy cigarettes for those circumscised before them. This is a type of secondary initiation that allows the newly circumcised to freely move around and talk or socialise with girls. The second ritual is what is known as Kuburwo mbiro (cleaning the sootfrom the penis). This is adapted from a practice in the past where young men and women initiated together had a teasing relationship. The men teased the women on what would happen if they did not accept to have sex or if their soot was not dusted before marriage.

There were then many socially instituted checks to prevent premarital penetrative sex including participating in $N g$ wiko where young men and women could explore their bodies and experience sexual pleasure without penetration. Participation in Ngwiko was in this way also a form of moral testing by being presented with actual experiences (Ahlberg 1994, 1997, Mugambi 1989). ${ }^{4}$ The practice has changed to mean that the boys can have the soot cleaned through penetrative sex, soon after circumcision. Since the ritual has to do with cleansing or more specifically cleaning the soot, condom use is therefore discouraged (Kamau 2007)..$^{5}$ They use a great deal of proverbs and songs for educating, but also for pressurising the newly circumcised to conform to the rituals and violence is not uncommon against those who may refuse to follow the rituals (Kamau et al 2006).

It seems that recruitment into what has come to be known as the Mungiki phenomenon may have roots in these developments, although the Mungiki as a movement of young men need to be understood broadly in its political, economic and religious contexts (Wamue 2001). ${ }^{6}$

The conclusions to draw from these examples of ambivalence, whether from within Africa or from without, whether on the attack or on the defence of African cultural and moral systems, is that reflexive evaluation is critical in order to avoid attributing or explaining conditions, issues and practices as manifestations of "African culture" or as "un-African".

To get a fuller picture of the complex contexts within which the concept 
of wellness will be translated into action, it is necessary, to reflect on some skirmishes or the specific ways the scripts, be they technical or religious are dramatised or acted on by a range of actors, individuals as well as institutions, and dilemmas or paradoxes which have emerged.

\section{Selected Scripts, Dramas and Dilemmas}

In this section, we highlight examples of how discourses or scripts have been acted on by individuals and institutions. We highlight, also, how these actions and their contexts could be reshaping the discourses. Warlike methods and messages, discrediting sexuality outside the defined boundaries, combined with a focus on negative consequences of sexuality meant to scare young people in particular, is what we refer to as prohibitive silence. It is prohibitive in the sense that there is a great deal of loud noise about the "ought and ought not" to, mainly no sex outside marriage and no condom use.

It is silence in the way it cannot as much as pronounce the pleasurable, the erotic, the desires or the positive aspects of sexuality. The young people are discouraged from having relationships which could result in premarital sex, even though the love discourse may allow sexual indulgence as long as people are in love irrespective of marital status. It is the tension between the public pronouncements and performance and the private realm of individual actors manifested in the prohibitive silence that is the challenge when figuring how to transform wellness from a concept to action strategies.

A drama unfolded in Kenya when the International Planned Parenthood Federation (IPPF), a technical discourse institution, made plans in 1985, to supply contraceptives to girls from the age of ten years to prevent early teenage pregnancies. This plan was strongly opposed. Parents in the central part of Kenya for example, resisted by advising their primary school daughters against drinking the school milk which had been introduced by the government, on suspicion that the milk could be laced with contraceptives (Weekly Review, February 21, 1986). This forced the Family Planning Association of Kenya (FPAK), an affiliate of the IPPF, to publicly disassociate itself from the IPPF's plan (Weekly Review, June 20, 1986).

Although there seem to be some softening taking place (Kamau 2007), the Catholic Church, among the Christian denominations has had an extremely hardline stand on sexuality. In February 1993, the Catholic Church protested against the proposal by the Kenyan Ministry of Education to make Family Life Education an examinable subject, forcing the government to abandon the idea.

Some Christian moral agents have become extremely aggressive and are 
currently using a number of tactics to enforce the Christian moral script.

One such tactic is violence as evident in the anti-abortion protests including the killing of doctors who perform the surgery and vandalising of abortion clinics (Horgan 1991).Another tactic is to enforce the "abstinence only sex education" by creating fear of what would happen to teenagers who fail to adhere to the Christian sexual moral script. Condom use is highly discredited for being ineffective in preventing sexually transmitted diseases and pregnancy (Green 2003) while premarital sex is said to lead to unhappy marriage in the future. Sexually active teens are portrayed as more likely to be depressed and suicidal and are talked into adopting secondary virginity (Bader 2005, Epstein 2005).

A third tactic is the use of "selective funding,"where donor agencies including humanitarian organisations with Christian influence increasingly channel funding through FBOs, while forcing the non-FBOs to declare not to engage in activities on issues such as abortion (Horgan 1991) and prostitution (CHANGE 2005).

Organisations funded for HIV and AIDS activities in such contexts thus censure themselves and are reluctant to include broad reproductive health for fear of loosing funding (Sindig 2005, Okello 2005, Pisan 2008). The consequences of these responses and dramas are felt in various ways. Apart from shortage of condoms in the African contexts as described by UNFPA (Godia 2004), abortion is becoming the major cause of maternal deaths for women aged15-19 years, the stigma produced and reproduced in these processes is perhaps the hardest obstacle in moving to sexual wellness perspective.

This discussion does not claim that the Christian moral scripts are uncontested. The history of Christian sexual moral discourse itself is characterised with shifts in level and intensity of torelance over sexual taboos and morals (Davies 1982, Preston 1996). These shifts indicate that although the Christian sexual morality has a utilitarian natural basis, sexual transgression remains the most abominable of sins in the contemporary period (Bujo 1990, Genovesi 1996, Wilson, 1989). Chaves (1994) argues that the broad shifts have meant no single sector of society can claim any necessary functional primacy and religion is just another institutution or organisational sphere where the elites struggle among themselves. Ellingson and colleagues (2001) describe, using examples from USA, how "local sexual norms and practices shape congregational responses to sexuality issues- in some cases limiting the voice of a congregation while in others driving the congregation towards a more public and politicised position." Johnson (2004) describes how Europeans migrating to USA used Christianity to justfy slavery of the black people and similarly how those enslaved used Christianity to define themselves as people of God.

In the context of AIDS, Messer (2004) notes that different denominations 
have taken different positions even when facing similar challenges. Some Christian denominations are for example, discussing how to revert the moral teaching by declaring life as more important than sex. In December 2003, the World Council of Churches in an ecumenical meeting with representatives from 24 churches and church-related organisations from 12 countries, declared stigmatisation and discrimination against people with HIV and AIDS as sin. The questions that observers ask are: Is this a sign of some mind-set change? Is AIDS assuming the role of catalyst enabling religious moral agents to start reflecting on sexual wellness rather than just moral judgement?

While some changes are taking place, there are interesting patterns in condom use to reflect on when thinking of promoting a sexual wellness perspective. Men for example, tend to use condoms only with sexual partners outside marriage. Evidence suggests there is fear that asking for a condom within a firm relationship could be interpreted as a sign that a partner is unfaithful, has a disease or has no trust in the partner. The risk of infection is in this case conceptualised less in the sexual act, as it is in the sexual partner and the relationship (Squire 1993). Moreover, male clients of women in prostitution reportedly opt to pay a higher price to have sex without a condom, although this is one of sexual encounters regarded epidemiologically as most risky. For the men, the issue of risk does not arise as they pursue what they regard as more pleasurable sex regardless of the needs of women or the risks the men expose themselves to. Although women in prostitution may be empowered to demand or negotiate for protection, their economic status and vulnerability in gender power terms limit them in exercising acquired skills. Patterns of condom use are reportedly different among homosexual men. Evidence in the context of AIDS suggest that homosexual men more than other social groups, adopted condoms at least at the early stages, when the epidemic was largely viewed as a problem of homosexuality (Squire 1993).

With treatment increasingly becoming available and AIDS becoming another chronic disease (Rosegarten et al 2004, Robins 2005), homosexual men may have similarly become less strict and information about ones status no longer a moral obligation (Ainslie 2002). The widespread use of condom among homosexual men however introduces a new dimension to the moral discourses. Why would homosexual men adopt the condom more than other groups? Does it not interrupt sexual pleasure as heterosexual men claim?

According to Squire (1993), condom adoption among homosexual men was an act of resistance on their part against the very opposition they experience from the religious moral agents and the rest of the society. It is also partly to do with the meaning of the sexual expression. Homosexuality is more associated with sexual pleasure rather than procreation. This means 
the risk is seen in the sexual act itself (Squire 1993) and it is there that prevention should take place. This contrasts with heterosexuality where the risk is seen in the persons or social categories epidemiologically or according to technical discourses are defined as "risk groups."

\section{Discussion: Translating Sexual Wellness to Action}

This paper has tried to map the various ways discourses on sexuality, whether technical or religious, influence sexual expression and practice. The two cases from which the questions addressed derive have two messages. The first illuminates the dilemmas experienced and expressed by the young people living within contexts of prohibitive silences.

The second reflects on or gives a glimpse of the value that could be accrued from basing the debate on people's cultural history. This is not an issue of going back to the past, but rather using the past and the local contexts as a methodology to help reflect on the present; to question the self, to gain insights of the changes which have and continue to take place, and more importantly to explore how to build on the insider perspective.

The paper was not meant to present guidelines on how to move wellness from concept to action. On the contrary, the aim was to map the complexities entailed in any serious attempt to change mind-sets regarding sexuality. Some of the complexities relates to moral dispositions and more importantly, how the discourses, whether the technical/public health or the religious stipulate a type of ideal universal sexuality.

In their different ways the discourses appeal to the moral sensitivity of the individual actor, ignoring that the individual is a part of a wider frame of reference. The discrepancies, the dilemmas and the protests observed in this paper reflect tensions between the public discourse as situated practice and the embeddedness of the individual actor in the multiple discourses. The issue of condom use is a case in point where the public health discourse appeals to individuals without taking account of the contexualised social meanings of different sexual relationships, gender power differences, economic status and sexual orientation.

A related complex phenomenon is the representation of Africa where in spite of being integrated into the world systems in specific ways, there is still a strong tendency to present it as frozen in time. This implies that the hoards of humanitarian organisations, international as well as local ones, could be pulling the wrong notes, thus unleashing the negative development we see all over (Shivji 2007, Shiva 2004, Klein 2007). More than ever before, understanding 
how Africa is represented and building on specific contexts, could make an appropriate point in the sort of change needed to liberate the minds in oder to build a positive view of sexuality.

The question however still remains regarding where and how this history can be imparted to offer the positive view needed to empower people. The postcolonial lenses point to a history that nearly suffocated local cultures and sexualities and although they are represented as though they are in their original forms, the half belonging is challenging as is clear from the ambivalences among the Africans themselves.

The ritual of circumcision continue to be regarded as still central in the making of men, without understanding what changes have taken place, to make it not only different but also violent.

In conclusion, the complexity mapped in this paper calls for a move from the current linear thinking as noted in the HIV and AIDS interventions, be they research or development, to the idea of learning by doing, which implies cyclical movements - a type of "two steps and a turn" in order to allow for learning, unlearning and relearning or a reflexivity that facilitates questioning of the "taken for granted" thus allowing new understanding and appropriate action.

\section{Endnotes}

${ }^{1}$ The missionaries for example banned the practice of Ngwiko mentioned in this paper, because they could not farthom how young people could avoid sexual pentration.

${ }^{2}$ Becker (2003) advances a similar view about African church leaders in northern Namimbia, but also notes how the local elite distort cultural practices by adopting only certain aspects of rituals in weddings ceremonies.

${ }^{3}$ Edward Green moreover, avoids to articulate that the change of emphasis in Uganda is a recent phenomenon and that it was only after receiving the President's Emergency Plan for AIDS Relief (PEPFAR) that the president of Uganda made a complete turn around from the openness he had earlier been praised for by many western donors as unique in the region, to preaching virginity and moral conduct as African values (Epstein 2005, Kalinaki 2005).

${ }^{4}$ Unlike the Christian moral regime, the Kikuyu then recognised that the young people had a sexuality. This practice where penetration was not allowed is confused by some western scholars as a sign that sexuality in Africa was for procreation only.

${ }^{5}$ The boys moreover argue that the condom is in any case also discouraged by the church which has also become active in the circumcision itself and counseling the boys before and after circumcision.

${ }^{6}$ Instead of taking the hardline action the government has taken to root out the Mungiki, policy should be directed at reflecting on the institution of male circumcision and its changing forms particularly how the boys shoulder the burden of a ritual in 
contexts of poverty. Such reflection is opportune especially given the current political manifestations where the cutting of the penis or not cutting, health benefits aside, has become politicised in ways that make managing ethnic diversity, masculinities, gender and sexual violence exceedingly complex in Kenya.

\section{References}

Ahlberg, B.M. 1994, Is there a Distinct African Sexuality? A Critical

Response To Caldwell et al. Africa, 64(2):220-242.

Ahlberg, B. M. Kimani, V.N. Kirumbi, L.W. Kaara, M.W. Krantz, I. 1997, The

Mwomboko Research Project. The Practice of male circumcision

in Central Kenya and its implications for the transmission and prevention of STD/HIV in Central Kenya. African Sociological

Review 1(1):66-81.

Ahlberg, B.M. Dare we dream of a future without AIDS? Challenges and opportunities for responsive social science research. In Helena Flam and Marcus Carson, eds. 2008, Rule Systems Theory: Explorations and Applications. Berlin/New York. Peter Lang (forthcoming)

Ainslie, D.C. 2002, AIDS and sex: Is warning a moral obligation? Health Care Analysis. 10:49-66.

Ani, M., 1994, Yurungu: An African-centred crique of European cultural thought and behaviour. Trenton NJ. AfricanWorld Press Inc p636. Arnfred, S. (ed), 2003, Re-thinking sexualities in Africa. Uppsala, The Nordic African Institute

Bader, E. Reproductive rights: Abstinence only education. Z Magazine Online, 18(1):1-6, January 2005. Available from: http://zmagazine. zmag.org/jan2005/baderpr0105.html. Accessed 2006-09-14

Baldwin, P. 2005, Disease and democracy: the industrialised world faces AIDS.

Berkeley, University of California Press

Becker, H. 2003, Efudula: Women's intiation, gender and sexual identities in colonial and post-colonial Northern Namibia. In Arnfred S (ed), Rethinking sexualities in Africa. Uppsala, The Nordic African Institute. Beyer, P. 1994, Religion and globalization. London, Sage Publications Birdsall, K. Faith-Based Responses to HIV/AIDS in South Africa. Centre for AIDS Development, Research and Evaluation CADRE. Available from: www.cadre.org.za/pdf/FBO-report.pdf. Accessed 2007-12-12

Bujo, B. 1990, Do we still need the ten commandments? A fundamental question in today's African world, Nairobi, St. Pauls Publications. Caldwell, J.C, Caldwell P and Quiggin P. 1989, The social context of AIDS. Pop. Dev. Rev. 15(2):185-233. 
Chamberlain, P. 2006, Undoing Reproductive Freedom: Christian right NGOs target the United Nations. A Report From Political Research Associates. www.publiceye.org.

Chambers I. 1999. History after humanism: responding to postcolonialism. Postcolonial Studies 2(1):37-42.

CHANGE (Centre for Health and Gender Equity). 2005, Implications of U.S. policy restriction for programs aimed at commercial sex workers and victims of trafficking worldwide. Policy Brief, November. www. genderhealth.org.

Chaves, M. 1994, Secularization as declining religious authority. Social Forces, 72 (3): 749-774.

Chernus, I. 2007, The theology of American empire.Available from: www. alternet.org/module/printversion/63785. Accessed November 8. Accessed 2007-12-12

Cornwall, A. and Brock, K. 2005, What do buzzwords do for development policy? A critical look at 'participation', 'empowerment' and 'poverty reduction'. Third World Quarterly 26(7):1043-1060.

Davies, C., 1982, Sexual taboos ans social boundaries. American Journal of Sociology. vol. 87, July 1981-May.

Ellingson, S. Tebbe, N. Van Haltsma, M. Laumann, E. O. 2001, Religion and the politics of sexuality. Journal of Contemporally Ethnography, 30 (1):3-35.

Epstein, H. 2005, God and the fight against AIDS. The New York Review of Books, 52(7).

Feffer, J. 2007, Spreading the word. Foregn Policy In Focus (FPIF) Available from: www.fpif.org/fpifxt/4835 Accessed 2007-12-29.

Feldman, D.A., 2003, Reassesing AIDS priorities for Africa: ABC vs ACCDGLMT. AIDS \& Anthropology Bulletin. The Newsletter of the AIDS and Anthropology Research Group. 15(2):5-8.

Genovesi, V.I., 1996, In pursuit of love: Catholic morality and human sexuality. Collegiville; The Liturgica Press.

Green, C. E. 2003. Rethinking AIDS prevention: Learning from successes in developing countries. Praeger Publishers

Godia, J. 2004, Tragedy of three condoms a year. The Sunday Standard. September 2.

Hallinan, C. 2007, The religion of divide and conquer. Foreign Policy in Focus. Available from: www.fpip.ord/fpiftxt/4607. Accessed 2007-12-12.

Harmon-Snow, K.A.B., D, 2007, Three cheers for Eve Ensler: Propaganda, white collar crime, and sexual atrocities in Eastern Congo $Z$ Magazine Online. Available from: www.zmag.org/content/print 
article.cfm?itemID=14128\&sectionID=2. Accessed 2007-12-12

Hearn, J. 2002, The 'Invisible NGO: US evangelical missions in Kenya. Journal of religion in Africa 32(1):32-60.

Hoodbhoy, M. Flayherty, M.S. and Higgins, T.E., 2005, Exporting despair: The human rights implications of US restrictions on foreign health care funding in Kenya. Fordham International Law Journal 29(1):1-26. Horgan, J 1991,Exporting Misery: A U.S. Abortion Ruling Affects Women's Health World-wide. Scintific American, 265(2):16.

JAL. 1979, The rejection of the marriage bill in Kenya. Journal of African Law, 23(2):109-114.

Johnson, S. 2004, The myth of Ham in the nineteenth-century American

Christianity. New York, Palgrave Macmillan p187.

Jones, N. 2008, Undoing what keeps us bound. RH Reality Check. Available from:www.rhrealitycheck.org/node/6149/print Accessed 2007-12-12.

Kalinaki, D.K., 2005. AIDS activists criticise Museveni over abstinence call. The East African. Dec 27, 2004-Jan 2.

Kamau, A. Bornemann, R. and Laaser, U. 2006, Psychosocial influences on adolescent sexuality and identity in rural Kenya. Health Sociology Review: The International Journal of Health Sociology, 15 (3).

Kamau, A., 2007, The owners of the body are not involved: examining adolescents' access, provision and use of preventive reproductive helth services in Central Kenya. Germany, VDM Verlag Dr Muller, Saarbrucken.

Klein, M. 2007, The shock doctrine. London, Penguine Books.

Konchansky, G.E. and Herrmann, F., 2004, Shame and scandal: Clinical and Canon Law perspectives on the crisis in the priesthood. International Journal of Law and Psychiatry, 27:299-319.

Kroeger, K., 2003, Anthropologists debate paradigm shifts in AIDS prevention. AIDS \& Anthropology Bulletin. The Newsletter of the AIDS and Anthropology Research Group. 15(2):1-2.

Kuppan, I. and Quintal, A. 2006, Churches speak out against marriage bill. The Daily News.

Leichter, H. M., 1991, Free to be Foolish:Politics and Health Promotion in the United States and Great Britain. Princeton University Press 228-232.

Levine, C. 1991, AIDS Prevention and Education: Reframimg the Message. AIDS Education and Prevention, 3(2):147-163.

Lutz, C. A. and Abu-Lughod, L. 1990, Language and the politics of emotion. Cambridge University Press, Cambridge.

Maes, Y., 1999, The cannibal's wife: a memoir. New York, Herodias Inc. Maguire, C. 2003. A papacy's 25 years of unfulfilled potential. Los Angeles 


\section{Times, October 17.}

Marshall, M. and Taylor, N., 2006, Tackling HIV and AIDS with faith-based communities: Learning from attitudes on gender relations and sexual rights within local evangelical churches in Burkina Faso, Zimbabwe, and South Africa. Gender and Development, 14(3):363-374.

Mbembe, A., 1992, Provisional notes on postcolony. Africa 62(1):3-34.

Mbembe, A. and Nuttall, S., 2004. Writing the world from an African metropolis. Public Culture, 16(3):347-372.

McClintock, A., 1992, The Angel of progress: Pitfalls of the term "Postcolonialism. Social Text, 31/32:84-98.

Messer, D.E., 2004a, Global AIDS and 'Thoelogy of A Few'. National Catholic Reporter 2(31), November 30. NCRonline.org.

Messer, D.E., 2004b, Breaking the conspiracy of silence: Christian churches and the global AIDS cricis. Minneapolis, Fortress Press.

Mitchell, B.M. and Salsbury, R.E., 1996, Multicultural education: An international guide to research, policies and programmes. Greenwood Publishers.

Mugambi, J.N.K., 1989, African heritage and contemporary Christianity. Longman, Kenya.

Narayan, U., 2000, Essence of culture and a sense of history: A feminist critique of cultural essentialism. In Narayan U. and Harding, S. Decentering the center: Philosophy for a multicultural, postcolonial, and feminist world. Indiana University Press p330.

Okello, R., 2005, Health: The divergence of AIDS, and sexual and reproductive rights. IPS-Inter Service News.http://www.ipsnews.net/ print.asp?idnews=25397. Patient, D. Blessing the condoms in Mozambique. AF-AIDS 2001, Available from:: http://archives. healthdev.net/af-aids. Accessed 2006-05-30. accessed 11.01.2007

Pisan E. 2008. The wisdom of whores: bureaucrats, brothels and the business of AIDS. London, Grant Books.

Preston, R.H., 1987, The future of Christian ethics. London, SCM Press Ltd p280.

Rabinow, P. (ed) 1984, The Foucault reader: An introduction to Foucault's thought, with major unpublished material. London, Punguin Books.

Ratele, K. 2003, Kinky politics. In Arnfred S (ed), Re-thinking sexualities in Africa. Uppsala, The Nordic African Institute.

Religious Coalition for Reproductive Choice. WE AFFIRM: Religious organisations support Reproductive Choice. Available from: www. rere. org. Accessed, 2007-12-29 
Robins, S. 2005, From "medical miracles" to normal(ised) medicine: AIDS treatment, activism and citizenship in UK and South Africa. IDS Working Paper 252.

Rosengarten, M. Imrie, J. Flowers, P. Davis, M.D. Hart, G.J. 2004, After the euphoria: HIV medical technologies from the perspective of their prescribers. Sociology of Health \& Illness 26(5):575-596.

Sears, A. 1991, AIDS and the Health of Nations: The Contradictions of Public Health. Critical Sociology, 18(2):31-51.

Shiva, V. 2004, How to end poverty: Making poverty history and the history of poverty. ZNET Commentary. www.zmag.org/Sustainers/ Content/2005-05/11Shiver.cfm. Accessed 2005-11-14.

Shivji, I.G., 2007, Silences in NGO discourse: The role and future of NGOs in Africa. Oxford, Fahamu: ISBN: 978-0-9545637-5-2.

Sindig, S.W.,2005, Does 'CNN'(condoms, Needles and Negotiation) work better than 'ABC' (Abstinence, Being Faithful and Condom Use) in Attacking the AIDS Epidemic? International Family Planning Perspectives, 31(1):38-40.

Squire, C., 1993, Women and AIDS: Psychological perspectives. London, Sage Publications,.

Time Magazine. The marrying kind. August 1979. Available from: www.time.com/time/magazine/article/0,9171,948747,00.htmlaccessed 2007-12-24

Urban, H. 2005, The secrets of the Kingdom: Spiritual discourse and material interesting the Bush administration. Discourse 27(1):141-166.

Wamue, G.N. 2001, Revisiting our indigenous shrines through Mungiki. Africa 100((400):453-467.

Wanyeki, L.M. 1996, Kenya-Population: Church burns condoms and AIDS materials. Inter-Press News Services (IPS). Available from:www.aegis. com/news/ap/1996/AP960808.html Accessd 1999-12-12.

Weekly Review, December 20, 1979

Weekly Review, February 211980.

Weekly Review, June 20, 1986

WHO, 2002. Sexual health definitions, Geneva, World Health Organisation. Wilson, B. R. 1989, Morality in the Evolution of the Modern Social System. The British Journal of Sociology, 36(3):315-332.

Corresponding Author:

Beth Maina Ahlberg

Skaraborg Institute for Research and Develoment 
Stationsgatan 12

54130 Skövde, Sweden

E-mail: beth@skaraborg-institute.se 